\title{
Critics urge reform of CITES endangered list
}

\section{London}

NEXT week's meeting of the Convention on International Trade in Endangered Species (CITES) in Kyoto, Japan, promises to be the most acrimonious in the treaty's 19-year history.

Already on the agenda is a fight between several southern African nations and their neighbours, teamed up with the industrialized world, over proposals to modify a three-year ban on trade in elthis battle is part of a larger issue that member nations must address: badly needed reform of CITES itself. The convention is performing poorly, according to leading conservation biologists, largely because it lacks appropriate criteria for ephant ivory. But informed observers say

deciding which species should be included under its trade controls.

South Africa and a consortium of five southern African nations (Zimbabwe, Botswana, Malawi, Namibia and Zambia) want to remove their thriving elephant populations from Appendix 1 of CITES, a listing that prohibits international trade in any elephant products. Despite the serious problems with elephant poaching elsewhere in Africa, these countries can claim that their populations are managed effectively. They want to sell ivory from elephants that are culled annually, to raise money for wildlife conservation. Another proposal, by Richard Leakey of the Kenyan Wildlife Service, would allow countries with healthy elephant populations to

\section{BRAZILIAN UNIVERSITIES}

\section{Soviet immigrants trigger debate}

\section{São Paulo}

A TRICKLE of scientists from the former Soviet Union who are headed towards Brazil has touched off a heated debate about the wisdom of hiring them at a time when native scientists are struggling to find jobs.

The current recession has meant few opportunities for faculty of any stripe. The notable exception is the University of São Paulo, the biggest and richest university in the country which, not coincidentally, can also boast of having the most talented faculty. The university, supported by the state of São Paulo, is putting the finishing touches to contracts with 10 scientists from abroad, including eight from the former Soviet Union. One has already arrived for a two-year stay, and his colleagues mostly engineers, physicists and mathematicians - are due this spring.

However, their hiring has been criticized by the president of the Brazilian Society for the Progress of Science, an umbrella group of scientists from various disciplines. Physicist Ennio Candotti, head of the society, believes that it is wrong for the university to hire foreigners at a time when the federal government is failing to provide necessary support for both working and would-be scientists.

Candotti pointed out that, since last May, the government has withheld funds for projects approved by an advisory body to the National Council for Scientific and Technological Development. Students who are studying abroad face similar delays. The problem came to a head earlier this month when several graduate students camped in front of foreign consulates and overseas agencies of the Bank of Brazil in cities where they are going to school to complain that they had not received their scholarship money. Their pro- tests convinced the government to release the funds.

"The idea of bringing scientists from abroad is a very good one", says Candotti. "But we must be careful not to lose our international credibility". Candotti is also worried that foreign scientists could face the same hardships as native researchers if the Brazilian government fails to sustain its support. "Our wages are not competitive internationally," he says. Although São Paulo plans to pay the immigrant foreign scientists expected this fall at the University of Brazilia will be earning only $\$ 1,200$ to $\$ 1,400$ a month.

São Paulo's pro-rector for research, Erney Plessman de Camargo, says that his university's recruitment of foreigners goes back more than 50 years, and that "we must keep the tradition of bringing competence [to the university' from abroad". He says that the university's $\$ 400$ million annual budget can easily absorb the cost of the new faculty.

The first contingent of Russian scientists has already arrived, and is making a difference. The University of Ijui, a small institution in the southern state of Rio Grande do Sul, has hired a small group of chemists, applied mathematicians and physicists from the Kazan Aviation Institute, a research facility that until recently has been closed to foreigners. They are currently teaching in a small town far from the country's main academic research centres.

The group are part of a continuing effort by the university to bring in foreign faculty for two-year periods. "We're very pleased with their work," says Telmo Frantz, the university's rector. "We hope that they stay."

Ricardo Bonalume scientists some $\$ 3,000$ to $\$ 3,500$ a month, resume the less-lucrative trade in elephant skins, while retaining the ivory trade ban. Conservationists hope that this compromise can unite the divided African nations.

South Africa's request has already been endorsed by a panel of CITES-appointed experts (see Nature 354, 175; 1991), and expert reports on requests from the other nations will be delivered near the start of the two-week Kyoto meeting. But even if these reports are also positive, delegates from many of the 112 CITES nations are expected to block the requests. UK environment secretary Michael Heseltine, for example, has already said Britain will oppose the move.

Anticipating a tough battle, the five black southern African nations, led by Zimbabwe, are launching a full-scale offensive to rewrite the convention itself. Zimbabwe and its allies want CITES to recognize that a carefully managed trade in animal products can benefit conservation efforts. They also argue that it is now almost impossible to cancel a species' CITES listing, even if populations are no longer endangered. CITES needs 'symmetrical' criteria for including and removing species from its appendices, the southern African countries argue.

These nations also want to abolish the 'Berne criteria', by which species are given their CITES listings. Under these rules, species qualify for inclusion in Appendix 1 of CITES if they are "currently threatened with extinction". The southern African countries argue that this definition is hopelessly vague, and leading conservation biologists agree. "They're not even criteria at all," says Georgina Mace, from the Institute of Zoology in London.

Last month, at a workshop in Cambridge organized by the World Conservation Union, conservation biologists agreed that many species have been given inappropriate CITES listings. At one point, Rowan Martin, director of research at the Zimbabwean National Parks Department, challenged biologists to name a single species that has benefited from a CITES listing. There were several moments of embarrassed silence before a handful of species were put forward.

The southern African nations want to replace the Berne criteria with new definitions developed for the Union by Mace and Russell Lande, from the University of Oregon. The new definition would cover those species that have a 20 per cent chance of becoming extinct within 20 years, or ten generations (Conservation Biology 5 , $148 ; 1991)$.

Mace believes that her criteria are not yet ready for general use; she says there have so far been no studies to test their usefulness. But she is hopeful that the 
discussion will bring modern conservation biology to bear on CITES, something that has so far happened only to a "very limited" extent.

Mace also believes that CITES needs to go beyond whether a species is endangered and take into account the effect of trade on wild populations. Many endangered species are not threatened by international trade, she says, while other species that are not yet endangered are declining rapidly as a result of trade.

The southern African countries are also trying to score political points over their opponents from the developed world. One audacious proposal is for the Atlantic herring to be placed in Appendix 1 of CITES, a move that would make international outlaws of many European fishermen.

James Martin Jones, from the World Wide Fund for Nature (WWF) says the herring is now recovering from the overfishing of the 1970 s, so that any such proposal should be defeated easily. But "had they gone for haddock or even cod, they could have made a strong case," he says. Nevertheless, the underlying message of the southern African countries is clear: countries that have no elephant populations of their own should not be laying down the rules for elephant conservation.

Few observers are willing to predict the outcome of the vote in Kyoto on southern Africa's elephant populations. But if all of Africa can come to a consensus, the developed world is expected to agree with its line.

Peter Aldhous

ANIMAL RESEARCH

\section{Importer indicted}

\section{Washington}

MATTHEW Block, president of Miami-based Worldwide Primate, a major US importer of research primates, was indicted last week by a federal grand jury for violating the Endangered Species Act. In the fourcount indictment, the grand jury charged Block with attempting to ship six baby orangutans out of Bangkok, Thailand.

Orangutans are an endangered species and may not be sold or transported without a special licence. According to a statement released by the US Attorney for the Southern District of Florida, most of the smuggled orangutans, which were labelled as birds, "succumbed to the stress of their captivity and poor handling" despite an international effort to save them after they were intercepted by Thai authorities in 1990. If convicted on all counts, Block faces up to 12 years in prison and $\$ 700,000$ in fines.

Last year, Block sued Shirley McGreal, chairwoman of the International Primate Protection League, claiming that she had damaged his reputation in the course of helping the US authorities. That case is still pending. Christopher Anderson

\section{Warning on population growth}

\section{London}

THE US National Academy of Sciences and the Royal Society of London have this week published a joint statement on present global problems that gives central attention to world population growth. Among other things, the statement calls for an inter-academy conference, likely to be held in Sweden next year.

Although the frequent US reports by the National Research Council are technically opinions to which the council of the US academy assents, the Royal Society has traditionally been shy of committing itself to opinions on public policy, citing the difficulty of reaching agreement within its council. The joint statement is claimed to be an occasion without precedent.

This is also the first time the two academies have issued a joint statement on a matter of general interest, reflecting (the statement says) joint "deep concern". The statement took two years to write, and was completed only a few weeks ago. A visit last year to London by Carl Djerassi appears to have helped powerfully to crystallize the text now published.

Next year's conference will be organized by the Royal Swedish Academy of Sciences, and will probably be held in the spring. Other academies worldwide are being invited to act as co-sponsors.

The declaration links the estimated growth of the world's population of 100 million a year with the way in which human activities are producing "major changes in the global environment". If growth remains unchecked, and the patterns of human activity unchanged, according to the statement, "science and technology may not be able to prevent either irreversible degradation of the environment or continued poverty for much of the world".

Population estimates are based on the 1991 report of the UN Population Fund, which noted an acceleration of population growth since 1984. Even assuming sustained decreases of fertility towards the replacement level of 2.1 offspring per woman per lifetime, the statement says that world population may be 10,500 million in 2050 , close on 90 per cent of it in developing countries.

The two academies argue that both developed and developing countries add to the pressure on the environment. Developed countries, with 85 per cent of the world's gross national product, account for most resource consumption; their emission of carbon dioxide "has the potential for altering global climate", with global consequences. Although resource consumption per head is lower in developing countries, the pressure of population and for economic growth may have similar consequences.

Present patterns of activity coupled with population growth, the statement says, should make "even those most optimistic about future scientific progress pause". It says that some environmental changes may irreversibly damage the Earth's capacity to sustain life, noting that many species have already disappeared or are likely to do so.

The academies go on to urge that this year's UN Conference on Environment and Development should acknowledge that both human activities and population growth are essential to a consideration of a sustainable world society. They urge more "effective family planning", coupled with economic and social change, for the developing countries, and conservation, recycling, substitution and the more efficient use of energy for industrialized states. Mitigating carbon dioxide emissions is an immediate goal.

Turning to how science can mitigate these problems, the academies back (in order) "new generations of contraceptives", alternative energy sources, improved agriculture, animal and plant genetics, biotechnology and public health (including vaccines against infections such as malaria and AIDS).

Biodiversity gets a special commendation. The statement says it is important that the "nature and dimension" of the world's biodiversity should be understood. But the present rate at which species are disappearing is the greatest in 65 million years (since the Cretaceous-Tertiary extinction). The "loss of biodiversity ... . is irreversible ... and has serious consequences for the human prospect in the future".

The statement also warns that people should not expect too much from science. It says that while research and innovation can mitigate many of the world's problems, "it is not prudent to rely on science and technology alone to solve problems created by rapid population growth, wasteful resource consumption and harmful human practices".

The statement refers to most of the issues now conspicuous on the agenda of environmentalists, some of which are controversial. But it stops short of seriously contentious questions, such as the policy of the US government on the provision of overseas aid linked with abortion and the position of the Roman Catholic Church.

More generally, the statement concludes with a commendation of "global policies ... to promote more rapid economic development throughout the world, more environmentally benign patterns of human activity and a more rapid stabilization of world population".

John Maddox 